\title{
Scientometric Evaluation of Sports Journals in Russia
}

\author{
Viktor A. Blaginin \\ Ural State University of Economics \\ Ekaterinburg, Russian Federation \\ v.a.blaginin@usue.ru
}

\author{
Veronika A. Zyryanova \\ Ural State University of Economics \\ Ekaterinburg, Russian Federation \\ zva@usue.ru
}

\author{
Polina E. Akulova \\ Ural State University of Economics \\ Ekaterinburg, Russian Federation
}

\begin{abstract}
The article is devoted to a scientometric review of Russian journals of sports science. The tops of such journals are presented for several scientometric indicators. Indicators are selected on the basis of the most used and qualitatively reflecting the actual situation. The authors conclude that the number of journals of this scientific category in the country is sufficient, but they should work towards increasing the citing mass and distribution of publications not only in the domestic area, but also on a global scale. Journals with high growth potential, but which are worth finalizing some aspects of functioning, are presented. The need for a competent editorial policy in these publications is indicated.
\end{abstract}

Keywords-scientometrics; scientific journal; scientific direction; sport; sports scientific direction.

\section{INTRODUCTION}

To date, the national bibliographic database of scientific citation "Russian Science Citation Index" contains 66,423 scientific journals [1]. Of this amount, on the subject of "Physical Culture and Sports" - 133 scientific journals (of which 16 are on the list of Higher Attestation Commission). Journals in this area are specific and have their own characteristics [2]. The relevance of the study is to consider the performance of Russian journals on the subject of "Physical Culture and Sports" and evaluate their ability to achieve the results of the journals included in the Web of Science and Scopus database. The large 30-year world history of the development of the sports scientific field explains the need for its further development in conjunction with other branches of knowledge, including from a geographical point of view [3].

\section{RESEARCH METHODOLOGY}

The study is based on an analytical assessment of journal scientometric indicators in the scientific citation database of the Russian Science Citation Index [4]. Take a number of indicators as a basis, such as the Science Index and two-year impact factor as the main ones in the database for accelerated analysis and ranking of Russian scientific journals. Additional indicators are not taken into account separately, due to the fact that they are reflected in the Science Index integrated indicator. Based on the results, pits should be formed between the ratings in these indicators, taking into account the Russian specifics, which makes it possible to develop a mechanism to level the gap between domestic sports science and foreign ones. The aim of the study is not to compare Russian journals with foreign counterparts in the Web of Science and Scopus databases, which makes it possible to continue the analysis in the following publications.

\section{RESULTS AND DISCUSSION}

As part of the research methodology, a sample was made at the RSCI for two indicators. Firstly, the top 20 scientific journals on the subject of "Physical education and sport" (Table 1). Indicator: two-year impact factor, which is calculated on the basis of citation data for the journal in the RSCI for the previous two years [5]. When calculating the impact factor, the number of links made in the accounting year from all journals processed by the RSCI to articles published in this journal for the previous two years (or five years) is divided by the total number of these articles.

TABLE I. TOP 20 RUSSIAN JOURNALS. INDICATOR: 2-YEAR-OLD IF

\begin{tabular}{|l|l|l|}
\hline Rank & Journal & IF \\
\hline 1. & Theory and practice of physical education & 0,679 \\
\hline 2. & Bulletin of sports science & 0,447 \\
\hline 3. & Sports psychologist & 0,426 \\
\hline 4. & Physical culture, sport - science and practice & 0,424 \\
\hline 5. & Scientific notes of the University. P.F. Lesgafta & 0,319 \\
\hline 6. & Physical Culture and Health & 0,257 \\
\hline 7. & Science and sport: current trends & 0,248 \\
\hline
\end{tabular}




\begin{tabular}{|l|l|l|}
8. & $\begin{array}{l}\text { Pedagogical-psychological and biomedical problems } \\
\text { of physical education and sport }\end{array}$ & 0,246 \\
\hline 9. & Sport: economics, law, management & 0,242 \\
\hline 10. & $\begin{array}{l}\text { Bulletin of Tula State University. Physical Culture. } \\
\text { Sport }\end{array}$ & 0,236 \\
\hline 11. & Physical education: upbringing, education, training & 0,219 \\
\hline 12. & Extreme human activities & 0,211 \\
\hline 13. & Physical education and sports training & 0,194 \\
\hline 14. & OlymPlus. Humanitarian version & 0,188 \\
\hline 15. & Science in Olympic Sports & 0,171 \\
\hline 16. & Physical Culture. Sport. Tourism. Motor recreation & 0,163 \\
\hline 17. & $\begin{array}{l}\text { Human health, theory and methods of physical } \\
\text { education and sports }\end{array}$ & 0,154 \\
\hline 18. & Actual issues of physical education and sports & 0,138 \\
\hline 19. & $\begin{array}{l}\text { Bulletin of the Adygea State University. Series 3: } \\
\text { Pedagogy and Psychology }\end{array}$ & 0,136 \\
\hline 20. & Scientific sports bulletin of the Urals and Siberia & 0,131 \\
\hline
\end{tabular}

The first thing that catches your eye is the extremely low impact factor even in a leading journal. IF less than one is not very characteristic for top industry journals, it does not depend on additional circumstances. This is most likely explained by the fact that many journals that are partially focused on sports research are moving to the scientific direction "Medicine", "Life Sciences" and others [6]. The second is that the gap between the first place and the second is almost $50 \%$, which is extremely high. It is explained, again, by the fact that the first journal is the oldest in Russia and is included in foreign scientometric databases.

The second front of the study was the category of journals included in the top 20 journals in the Science Index ranking (Table 2). The rating is formed on the basis of two scientometric indicators: the average number of references in the lists of cited literature to articles in RSCI journals; average percentage of links from publications of the current year to articles in a journal over the past 5 years in relation to all links to this journal (for all years).

Here, the same trends are noticeable as in the previous rating. An unequivocal leader has been identified, the lag of the others is quite large. There is, of course, a direct relationship between these indicators, but a five-year impact factor, which is often significantly lower than a two-year period, is included in the methodology for calculating the Science Index. Another feature is that the TOP-20 journals the authors of the article barely typed [7]. The Science Index in the denominator has the Herfindahl index for citing journals, and the fact that in many journals this integral indicator is practically zero indicates the closure of scientific journals not only at the national level, but also regionally - this phenomenon is called scientometric implosion of journals [8].

TABLE II. TOP 20 RUSSIAN JOURNALS. INDICATOR: SCIENCEINDEX

\begin{tabular}{|l|l|l|}
\hline Rank & Journal & SI \\
\hline 1. & Theory and practice of physical education & 0,681 \\
\hline 2. & Bulletin of sports science & 0,455 \\
\hline 3. & Science and sport: current trends & 0,394 \\
\hline
\end{tabular}

\begin{tabular}{|c|c|c|}
\hline 4. & Physical education of students & 0,284 \\
\hline 5. & Sports psychologist & 0,249 \\
\hline 6. & $\begin{array}{l}\text { Bulletin of Tula State University. Physical Culture. } \\
\text { Sport }\end{array}$ & 0,220 \\
\hline 7. & Physical culture, sport - science and practice & 0,216 \\
\hline 8. & Science in Olympic Sports & 0,201 \\
\hline 9. & Physical Culture and Health & 0,195 \\
\hline 10. & Sport: economics, law, management & 0,194 \\
\hline 11. & Physical education: upbringing, education, training & 0,191 \\
\hline 12. & Scientific notes of the University. P.F. Lesgafta & 0,183 \\
\hline 13. & Physical education and sports training & 0,160 \\
\hline 14. & Horse breeding and equestrian sport & 0,076 \\
\hline 15. & Extreme human activities & 0,061 \\
\hline 16. & $\begin{array}{l}\text { Pedagogy, psychology and biomedical problems of } \\
\text { physical education and sport }\end{array}$ & 0,057 \\
\hline 17. & $\begin{array}{l}\text { Bulletin of the Adygea State University. Series 3: } \\
\text { Pedagogy and Psychology }\end{array}$ & 0,057 \\
\hline 18. & Physical education at school & 0,054 \\
\hline 19. & $\begin{array}{l}\text { Pedagogical-psychological and biomedical problems } \\
\text { of physical education and sport }\end{array}$ & 0,053 \\
\hline 20. & Health, Education, and Security & 0,024 \\
\hline
\end{tabular}

Both lists were ranked from the highest indicator of the impact factor to the lowest and from the highest indicator in the ranking of the Science Index to the lowest and compared with each other. Thus, 15 journals were duplicate in both lists. It is gratifying that 5 journals in the lists did not match, this makes it possible to grow the entire sports scientific field in the country. Table 3 shows a comparison of the top 15 Russian journals in two categories.

After analyzing the table, you can see that several journals (No. 1, 2, 11, 13) are in a stable state according to scientometric indicators. However, as indicated in the methodology section, scientometric emissions are present when the discrepancy between the positions taken is extremely large. This option is extremely interesting for analysis. To consider the problem, we take two journals as the basis of the analysis: "Pedagogical-psychological and biomedical problems of physical education and sport" and "Science in Olympic sports".

As for the first journal, it is extremely famous for being issued in two versions: Russian and English, under the name "The Russian Journal of Physical Education and Sport". He has long been on the list of leading Russian publications and specializes in pedagogy of sports. In terms of impact factor, it is in eighth place, however, the penultimate of our top is Science Index. The journal has a high level of self-citation, in connection with which it is extremely high (this is negative, since a figure close to 0 is considered good) HerfindahlHirschman index. The journal has citations from an extremely narrow circle of Russian journals and there are practically no citations from foreign journals. The Gini index, which characterizes the uniform distribution of links to journal articles, is 0.79 and has been growing over the past years. 
TABLE III. TOP SPORTS JOURNALS IN RUSSIA ON IMPACT FACTOR AND SI

\begin{tabular}{|c|l|c|c|}
\hline Rank & Journal & on IF & on SI \\
\hline 1 & $\begin{array}{l}\text { Theory and practice of physical } \\
\text { education }\end{array}$ & 1 & 1 \\
\hline 2 & Bulletin of sports science & 2 & 2 \\
\hline 3 & Sports psychologist & 3 & 5 \\
\hline 4 & $\begin{array}{l}\text { Physical culture, sport - science and } \\
\text { practice }\end{array}$ & 4 & 7 \\
\hline 5 & $\begin{array}{l}\text { Scientific notes of the University. P.F. } \\
\text { Lesgafta }\end{array}$ & 5 & 12 \\
\hline 6 & Physical Culture and Health & 6 & 9 \\
\hline 7 & Science and sport: current trends & 7 & 3 \\
\hline 8 & $\begin{array}{l}\text { Pedagogical-psychological and } \\
\text { biomedical problems of physical } \\
\text { education and sport }\end{array}$ & 8 & 19 \\
\hline 9 & Sport: economics, law, management & 9 & 10 \\
\hline 10 & $\begin{array}{l}\text { Bulletin of Tula State University. } \\
\text { Physical Culture. Sport }\end{array}$ & 10 & 6 \\
\hline 11 & $\begin{array}{l}\text { Physical education: upbringing, } \\
\text { education, training }\end{array}$ & 11 & 11 \\
\hline 12 & Extreme human activities & 12 & 15 \\
\hline 13 & Physical education and sports training & 13 & 13 \\
\hline 14 & Science in Olympic Sports & 15 & 8 \\
\hline & $\begin{array}{l}\text { Bulletin of the Adygea State } \\
\text { University. Series 3: Pedagogy and }\end{array}$ & 19 & 17 \\
\hline 15 & \begin{tabular}{l} 
Psychology \\
\hline
\end{tabular} & & \\
\hline
\end{tabular}

The second journal described has 2 distinct features. Firstly, it is published by the National University of Physical Education and Sports of Ukraine, but at the same time it is registered in the RSCI. Secondly, it has a very narrow specialization exclusively in Olympic sports. Of course, he cannot compete on a par with Russian journals, since the readership is primarily in Ukraine, so the impact factor is lower than the average. At the same time, many referring journals in the RSCI are not registered, which led to a high level of Science Index.

\section{CONCLUSION}

In the Russian Federation, a minimum reserve has been provided for the development of a sports scientific field. There are more than 20 journals covering various aspects of the development of this branch of science, while many of them function in related scientific fields, and as the latest work on research fronts shows, interdisciplinary, joint and multidirectional articles give the maximum increase in citing mass and scientific knowledge in general $[9,10]$. The level of citation of sports journals is less than the world average and medium category, which means that it is necessary to choose a course to exit from the closed distribution of journals only "among their own." Most journals lack precisely the promotional part of work on positioning in the world and domestic community, this is clearly seen in the number of citations for the most highly cited works in various journals from year to year. But at the same time, many publications are known abroad, have their own audience there. Among the editorial boards there are well-known scientists, which makes it possible to actually disseminate information about journals and develop scientific knowledge. The correct policy of journal publishers will quickly catch up with world sports science.

\section{References}

[1] Russian Science Citation Index (RSCI) [Electronic resource]: eLIBRARY portal. URL: https://elibrary.ru.

[2] Dart, J. (2014). Sports review: A content analysis of the international review for the sociology of sport, the journal of sport and social issues and the sociology of sport journal across 25 years. International Review for the Sociology of Sport, 49(6), 645-668. doi:10.1177/1012690212465736

[3] Seippel, Ø. (2018). Topics and trends: 30 years of sociology of sport. European Journal for Sport and Society, 15(3), 288-307. doi:10.1080/16138171.2018.1475098

[4] Moskaleva O. Russian Index of Science Citation: Overview and Review / O. Moskaleva, V. Pislyakov, I. Sterligov, M. Akoev, S. Shabanova // Proceedings of the 16th International Conference on Scientometrics \& Informetrics. Wuhan: International Society for Scientometrics and Informetrics, 2017. P. 1076-1086.

[5] Garfield E. Citation Indexing: Its Theory and Application in Science, Technology, and Humanities / E. Garfield. New York: Wiley. 1979. P. 274.

[6] Voronkova, O.V. Key directions of scientific research in the Russian Federation / O.V. Voronkova // Science and business: development paths. - M .: TMBprint. - 2014. - No. 5 (35). - S. 87-90.

[7] Kosten, J. A classification of the use of research indicators / J. Kosten // Scientometrics. - 2016. - № 108. - P. 457-464.

[8] Sargsjan, S., Mirzoyan, A., \& Blaginin, V. (2019). Scientometric implosion of armenian journals. Paper presented at the 17th International Conference on Scientometrics and Informetrics, ISSI 2019 Proceedings, 2, pp. 2642-2643

[9] Research Fronts: Clarivate Institutes of Science and Development, Chinese Academy of Sciences. The National Science Library, Chinese Academy of Sciences, Clarivate Analytic [e-resource]. 2018. URL: https://clarivate.com/blog/science-research-connect/2018-researchfronts-report-updating-sciences-hottest-fields.

[10] Blaginin V. A., Matveeva A. I. Research fronts: a strategic imperative for the development of Russian science // Moscow Journal of Economics. 2016. No. 4. URL: https:/qje.su/en/otraslevaya-iregionalnaya-ekonomika/moskovskij-ekonomicheskij-zhurnal-4-201654 